\title{
Seven correlations between interpersonal violence and the progression of organised religion
}

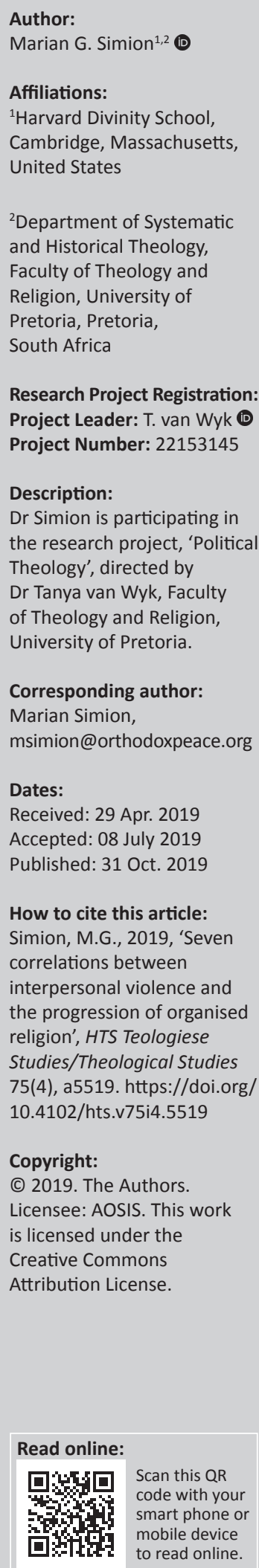

While the majority of organised religions determine the origins of religion itself in an act of divine revelation, social science literature takes an evolutionary perspective. Without engaging the question of origin of religion from either perspective, this article proposes seven correlations between interpersonal violence and the progression of organised religion by suggesting that interpersonal violence plays a significant role in the institutionalising process of organised religion. Although interpersonal violence does not necessarily cause the structuring of faith, it reinforces and provides solutions to the existing patterns of threat faced by the community, which together lead to the organisation of religion. The first part of this article (stages 1-4) surveys the psychology of violence by focusing on the theories of frustration-aggression, mimetic rivalry, triangulation and the genesis of scapegoating and guilt. The second part (stages 5-6) marks the transition from personal to social psychology and surveys violence in the primitive religion, as manifested in the ritualising process of the scapegoat, and the genesis of sacrifice. The third part (stage 7) highlights the complexity of ritual, ethics and doctrine, in the evolution of religion from a primitive state to an advanced organised institution.

Keywords: child psychology; doctrine; ethics; frustration-aggression; mimetic; nurturer; rivalry; religion; ritual; sacred-profane; sacrifice; scapegoat; seer; triangulation; violence.

\section{Overview}

Over the past two centuries, prominent philosophers, psychologists, social scientists and anthropologists such as Émile Durkheim (1969), Frazer (1996), Pritchard (1956), Freud (1998), Mircea Eliade (1974, 1987), Max Weber (1977, 1991), Girard (1977, 1979, 1986, 1987, 1996), Hubert and Mauss (1981), Burkert $(1979,1986,1996)$ and others have attempted to prove the social origins of religion in a deliberate effort to disclaim the commonly held view of religion as having divine origins. However, in their demonstrations, the effects of interpersonal violence upon the progression of organised religion had been somewhat overlooked. Girard and Burkert are perhaps the only eloquent scholars who understood the significance of interpersonal violence in the organisation of faith. Yet, both are vague in making clear the connection between interpersonal violence and the organisation of faith along the three basic pillars of religion - ritual, ethics and doctrine - and in explaining how, in their incremental development, these three pillars had been stimulated and informed by interpersonal violence.

Therefore, this article attempts to fill this structural gap.

In the first part (Violence and Psychology), the article will highlight four psychological foundations of interpersonal conflict on the assumption that the instincts observable in child psychology represent a constant of human behaviour. The first stage (Conflict) concentrates on child psychology by focusing on the mechanism of frustration-aggression deriving from the competition over an object equally desired by two competing babies, and on the mechanism of mimetic rivalry which arises because of competition. At the second stage (Triangulation), the conflict between the competing babies involves the triangulation of the nurturer, who is drawn into conflict as a mediator to ease tension. At the third stage (Scapegoat), the nurturer takes control of the conflict and deprives the competing babies of the desired object, which becomes a scapegoat and absorbs the fury of the competing babies. During the fourth stage (Guilt), the nurturer implements the emotional conscience of guilt and assesses full control over the situation.

The second part (Violence and Primitive Religion) marks the transition from personal to social psychology. With the progression in age of the competing babies, the assessment of guilt (along with the power to diagnose the cause of conflict and to find the appropriate cure to it) is transferred

Note: HTS 75th Anniversary Maake Masango Dedication. 
from the nurturer to the seer. Thus, the fifth stage (Ritual) introduces liminal triangulation, whereby the nurturer's mediating power is transferred from the nurturer to the seer, through rituals of transition and initiation. Following this transfer of power from the nurturer to the seer, several new phenomena come into play in the collective interest of the group. These new phenomena include the establishment of ethical norms through guilt and punishment, and the creation of narratives of meaning designed to justify ethical rules and seal them through the power of ritual.

Therefore, the sixth stage (Sacrifice) surveys the administration of mimetic violence by the society through the ritualising process of the scapegoat and the genesis of sacrifice visible in primitive religion. By separating between sacred and profane and by establishing rules on guilt and punishment, the society created religious meaning for stability and survival. With the historical progression of religion, the scapegoat and the sacrifice became decisive factors as the society separated the sacred from the profane by mashing together the shape of the ritual, public order and morality, while the finesse of doctrines was encoded in sacred narratives designed to reveal the meaning of life.

The third part (Symbolic Violence, Theological Superstructure and Structural Ambivalence) marked by the seventh stage (Organised Religion) focuses on the advanced state of faith standardisation and theological superstructure, whereby meaning is further developed and systematised into doctrines and sacred texts, the ethics of guilt and punishment are defined by various canons and religious laws, and the rituals of scapegoating and sacrifice are replaced by symbolic violence (Figure 1).

\section{Violence and psychology}

Why are human beings violent? Often, sanctioned as a 'noxious cocktail between genes and environment' (Moosajee 2003), the psychology violence had preoccupied every mind from every time and culture. Anchored into the two auxiliary verbs to have (economics) and to be (identity), psychology of violence is directed against the self (masochism) or against the other (sadism).

While it is widely believed that only violence can stop violence, ironically, if understood as adversarial retaliation, or vengeance, it is this very belief that reinforces its cyclical makeup. This is because, as Girard (1979:26) puts it, ' $[e]$ veryone wants to strike the last blow, and reprisal can thus follow reprisal without any true conclusion ever being reached'. The viral nature of uncontrolled violence is embedded into its mimetic feature, posing serious challenges to any process of immunisation against it. In fact, any effort to subdue uncontrolled violence creates new conditions in which violence can prosper. At the same time, controlled violence represents the only validity to the argument of 'fighting fire with fire', because this type of violence is rational rather than emotional in its nature.

Taking an evolutionary perspective, which subjects humanity exclusively to the killer instinct of the animal world and to the survival of the fittest, various scholars consider aggression

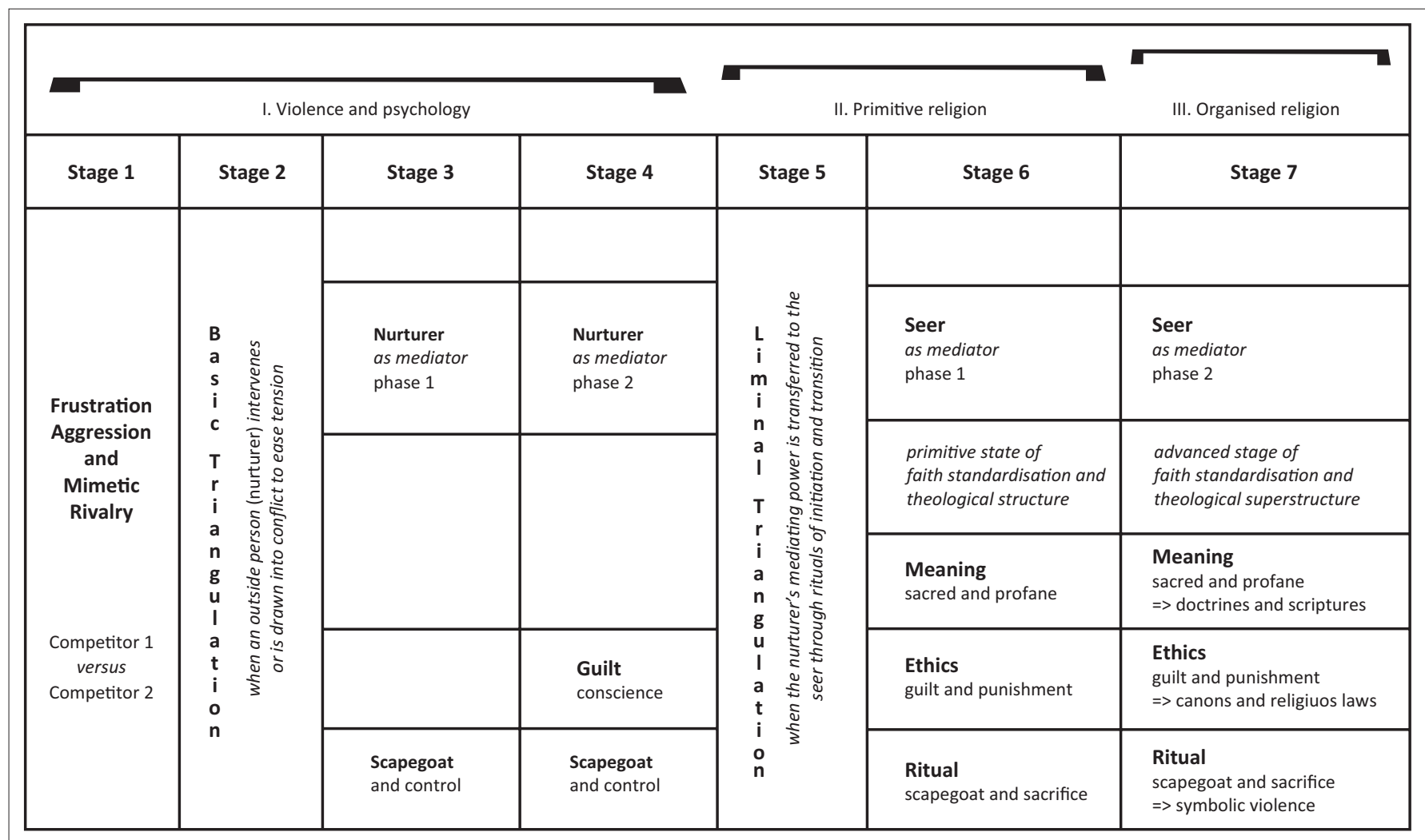

FIGURE 1: Seven correlations between interpersonal violence and the progression of organised religion. 
as being an intrinsic feature of the animal world. For instance, the Nobel Prize laureate Konrad Lorenz pointed out that aggression fulfils three functions: (1) species distribution balance, (2) selection of the strongest and (3) defence of the young.

Within these three functions, he points to a species of fish which, if deprived of its natural enemies such as male rivals with whom it habitually disputes territorial rights, turns its aggression against the members of its own family and destroys them (Girard 1979:2; Lorenz 1966). Yet, trapped by genetic determinism and natural selection theories, most of the modern scientists failed to fully comprehend the spiritual dimension of violence, instead arguing whether violence has a genetic makeup, or is a learned behaviour. In the history of humanity, one can observe that religion attempted and succeeded in engineering a reliable control mechanism against humanity's self-destruction - built from within the process itself - which differentiated between uncontrolled and controlled violence.

\section{Frustration-aggression and mimetic rivalry}

Dollard et al. (1939) in their work, Frustration and Aggression, have demonstrated that the failure to obtain an object mutually desired by two contenders leads to one's aggression against the other, thus starting a cycle of rivalry and violence. Later, Denzler, Förster and Liberman (2009:90-100) demonstrated that goal fulfilment decreases aggression. This is because, as Girard (1979) demonstrates, a human being desires mimetically in the sense that one person borrows the desire from another person, thus starting a cycle of rivalry that leads to violence. Furthermore, Girard demonstrated that if unappeased, violence seeks and always finds a surrogate victim (scapegoat) to be sacrificed, simply because 'sacrifice serves to protect the entire community from its own violence' (Girard 1979:8). According to the frustrationaggression theory (Dollard et al. 1939), when two contenders begin their competition over an object commonly sought, the first contender (the perpetrator) obtains the object of desire indirectly by harming the second contender. As a result, the second contender becomes a victim, whose first instinct is to retaliate in self-defence. Because of the retaliatory violence of the victim, the perpetrator is ready to strike for the second time, thus leading to a cycle of violence that could lead to the destruction of one of the contenders.

The trigger for frustration-aggression is the desire for possession, and as Girard demonstrates, people desire mimetically. One person borrows the desire from another person, thus encouraging each other's desire towards specific objects. Secondly, the borrowed desire causes rivalry between the two contenders, which can lead to violence. Therefore, in order to avoid an endless cycle of violence, the contenders focus their violence on a third party which becomes the scapegoat. This mechanism had been accurately depicted by René Girard in his cross-sectional analysis of myths and rituals, randomly selected from various historical and geographical settings (Girard 1977, 1979, 1986, 1987, 1996, 2001).

\section{Experimental mimesis and basic triangulation}

The mimetic mechanism of violence can be explained through the following experiment: in an empty room, we place two babies of equal age. Initially, the babies are content. Later, a toy is placed between the two babies. Then, the babies become curious and each wants the toy. One baby gets to the toy first and grabs it. Seeing this, the other baby comes and takes the toy from the first one. The first baby becomes frustrated and recovers the toy, triggering the other baby's anger (stage 1). During this process, the nurturer becomes aware that without external intervention, the babies will hurt each other. Consequently, the nurturer is compelled to intervene in the case in which the nurturer becomes triangulated (stage 2).

\section{Two valid hypotheses}

With the triangulation of the nurturer, the conflict either ends or continues to develop depending on the action of the nurturer. The decision of the nurturer generates two conditions for the conflict.

Firstly, if the nurturer removes the object of desire, the conflict reaches its conclusion in the sense that the object of desire becomes a scapegoat, and its removal absorbs and releases the fury of the babies (stage 3), as neither of them can have it.

Secondly, let us assume the hypothesis that the nurturer does not remove the toy but gives it to one baby, and places the other baby in a crib, behind the bars. In such case, several phenomena may begin to take shape. If the nurturer fails to remain an independent third party, then the nurturer becomes a co-competitor by joining the cause of one baby at the loss of the other. In a natural setting, such behaviour, although feasible and plausible, not only fails to end the conflict but also creates emotional damage to the competitors. By failing to remain an independent third party, the nurturer abandons the natural instinct to protect the young, thus displaying a deviant behaviour towards the babies. Such behaviour is also unnatural as it contradicts even the 'defense of the young' instinct noted by Konrad Lorenz in the animal world. Furthermore, as a result of the nurturer's failure to remain an independent third party, the babies will begin constructing their identity in relation to their feelings towards each other, feelings generated by the competition over the object of desire. Consequently, one baby begins seeing oneself as a winner (hence superior), while the other begins seeing oneself as a looser (hence inferior.) Furthermore, because the losing baby is still a potential threat to the winning baby, the winning baby begins contemplating how to build one's defence against any eventual aggression initiated by the losing baby. At the same time, the losing baby feels increasingly alienated and deprived, thus building a sense of resentment and desire to restore one's integrity. In time, the two babies build resentment against each other, thus laying the foundation for a culture of existential conflict.

If the nurturer removes the object of desire, then the object of desire absorbs the blame for the conflict, and it becomes an effective scapegoat, ending the conflict. Conversely, if the 
nurturer fails to remain an independent third party, then the blame is placed on the losing competitor, and the conflict continues (stage 4).

As one may conclude, this experiment reveals the germinating process of the main theories of collective violence: frustrationaggression (when the object of desire is introduced), alienationdeprivation (when the nurturer fails to be independent) and violence as a learned behaviour (when the two babies build their identities on resentment and fear of loss).

\section{Guilt, or where psychology and religion collide}

It is important to note that the intervention of the nurturer whatever that might be like - leads to the establishment of guilt conscience. Assuming that the nurturer removes the toy, an unavoidable conflict arises between the nurturer and the babies. During this new conflict (and succeeding conflicts occurring under the same paradigm), the nurturer will assume dominance over the situation by appealing to the sentiment of guilt. The sentiment of guilt is stimulated either through an appeal to the intervention of an imagined external threat (e.g. darkness and bogyman), through an appeal to the nurturer's own vulnerabilities, whereby the nurturer plays victim and starts fake-crying, or through an appeal to the babies' evolving ego, whereby the babies become aware of the importance of personal reputation. Therefore, strategies such as protecting one's reputation, fear of imagined threats and sympathy with the nurturer stimulate the growth of the sentiment of guilt as an inhibitor to aggression. The association between a negative deed and the consequential intervention of disturbing external forces represents the meeting place between psychology and religion. Fear of darkness becomes associated with evil; fear and compassion towards the nurturer become associated with the fearful love for spiritual authority; and personal reputation with religious conformity.

\section{Violence and primitive religion}

The link between the psychology of violence and primitive religion has gained increased attention over the past centuries.

Prominent studies oriented their attention towards patterns and themes, such as evil, sacrifice, scapegoat, primordial murder, martyrdom, terror, mimesis, myth, ritual and established links between religion and biology, psychology and ethology (Burkert 1979, 1986, 1996; Eliade 1987; Girard 1986, 1987, 2001; Juergensmeyer, Kitts \& Jerryson 2013; Lorenz 1966; Nayak 2000) and so on. According to archaeology, some of these patterns had been in existence for over 180000 years, as they can be traced back to the glacial period where specks of human behaviour displayed an obvious moral awareness of right and wrong associated with good and evil, while the hero worship, handlings of natural crises, as well as rituals for survival and fertility are present within manifestations of magic and fetishism, taboo and totemism, ancestor worship, tribal divinities and so on (Sparks 2013). Among the numerous topics of analysis, the patterns of mimesis, ritual, sacrifice and scapegoat appear as the universal forms of behaviour that stay at the basis of religion's institutionalisation. As it is apparent, these patterns pervaded the development of religion and influenced its structure in the way religion constructed its spiritual narratives, imposed patterns of behaviour and ritualised the meaning of life, giving each individual and generation a purpose for living within the pilgrimage from birth to death, into afterlife.

\section{Liminal triangulation: From personal to collective}

As far as evolutionary psychology is concerned, the transfer of emotional attitude towards violence from the private nurturing environment unto the public domain remains anchored in child psychology. Because of their efficacy, the mechanism of scapegoat and the sentiment of guilt developed by the nurturer were transferred unto the public domain where they led to the establishment of religious sacrifice. For the primitive society, guilt and sacrifice brought not only social stability but also separation of the public sphere between 'seen' (profane) and 'unseen' (sacred) (Eliade 1987:14-15).

In primitive societies, the transition from childhood to adulthood is marked by rites of passage, which the entire community ought to witness and partake. It is a process similar to the modern society which assigns the age when a boy or a girl is considered adult, and as such the nurturer is no longer socially liable for the boy's or girl's actions.

Therefore, in transitioning from childhood to adulthood (stage 5), the protective and pedagogical role played by the nurturer within the mimetic rivalry is being transferred to the seer - a spiritual specialist recognised as a storyteller, healer and mystical intermediary - Fisher (2008:49-55) who is socially entrusted to become the surrogate nurturer (e.g. abba, bhikkhu, elder, father, godfather, godmother, imam, mother, pujari, rabbi, rōshi, shaman, tsar-batushka and so on), and whose role becomes collective as to teach, mentor and protect the group against any danger from within or without.

As such, the sense of guilt that followed the emotional calamity of the primeval mimetic rivalry evolves from an inner feeling of wrongdoing (originally assessed and adjudicated by the nurturer, and which generated emotional remorse) to an outer recognition of transgression (now to be assessed by the seer), which from now on involves potential material compensation to the victim or physical punishment from the community. In other words, while the former perception of guilt represents an introspective psychological experience of the self - as in feeling guilty - the latter perception becomes a communal affair - as in being guilty. This transition is perhaps best explained by Burkert (1996:102-128), when he analyses the role of 'guilt and causality', within his understanding of the 'Creation of the Sacred'. In a similar sense, while in the 'Oedipus Complex', Sigmund Freud presented guilt as the feeling of remorse that followed a prehistoric crime that led to the establishment of totemic 
religion (Pals 2006:65-69), for Burkert, guilt has a juridical value, which favoured the establishment of law.

\section{Institutionalising a problem-solving mechanism}

The problem-solving mechanism discovered in the private nurturing environment of childhood is adopted in the social life where it is implemented through the power of ritual. Why ritual? Because, as Burkert (1979:35) stated, 'ritual is something people do'. Beyond such oversimplification, Burkert (1979) explained that:

$[R]$ itual is something atavistic, compulsive, nonsensical, at best circumstantial and superfluous, but at the same time something sacred and mysterious. (p. 35)

Why are rituals powerful? As Fisher (2008) noted, rituals are powerful because they:

$[O] f t e n$ take people out of everyday consciousness and into awareness of the presence of the sacred. In such altered states, participants may experience a heightened group consciousness that powerfully binds individuals together as a community. (p. 56)

As for the process in which the seer uses the power of ritual to take control of the conflict, Burkert (1996:103) describes it as being contingent upon four transformative stages: (1) the occurrence of evil, (2) the intervention of the seer as mediator, (3) the diagnosis of the hidden cause and (4) the application of the corresponding atonement.

Thus, we note that it is this very sequence that stays at the basis of the institutionalising process of religion because an institution represents a general solution to a collective problem. As Burkert (1996) puts it:

$[P]$ agan religious rituals and institutions are even more likely to emerge out of disaster and be decisively reinforced by it as the disastrous event is interpreted and cured by references to religious guilt, with the help of mediators who subsequently become active on behalf of the cults. (p. 113)

The group depends as much on the seer to provide stability as the seer depends on the group to offer its obedience. However, during this process, the seer takes full control not only over the direction of the dispute but also over the general behaviour of the group, which is now forced to conform with a set of new rules designed to increase the power of the seer. This is precisely why, for Burkert (1996):

$[T]$ he role of the mediators deserves special attention: the seers, the oracles, the shamans, the medicine men, the rabbis - in short, persons who 'know more' and hence may help against all kinds of present evil, make good whatever has gone wrong. They are greatly needed because in practical experience the evil cause is hidden, evident as it may appear in the cautionary tale composed afterward. (p. 116)

In interpreting 'the hidden things', the seer creates a 'story' which he or she imposes as the 'truth', by appealing to the power of scapegoating and sacrifice - two phenomena credited to trigger the process of standardising the religious behaviour (Girard 1987:3-131). Thus, the problem-solving mechanism becomes justified through emerging narratives that reach sequential clarity only in the later stages. As Burkert (1996) explains the process itself:

$[T]$ he pattern easily develops into a tale. The very question 'why?' calls for a tale. When people are faced with strange behavior, they say, 'tell me why are you doing this?' Sense is created by finding a way to speak coherently about events. One result may be the typical cautionary tale. The tale, however, is likely to invert the sequence experienced in practical life: it starts with the original fault or mistake, whether an infraction of taboo, or violation of law, order, or morality, or just some rash and imprudent action; it explains how, in consequence, evil manifests itself; it goes on to describe how it was finally overcome by the appropriate means. Tales allow variations that include catastrophe in the end, but in practical life we cling optimistically to the possibility of overcoming disaster. (pp. 112-113)

From an evolutionary perspective, the phenomena of scapegoat and sacrifice had been considered some of the most primitive instruments of ritual performance (Simion 2017:2). While the scapegoat phenomenon can be regarded as an inferior behaviour and a primal instinct - as, according to Lorenz $(1966: 51,175)$, this is found also in the animal world it predates (if not conditions) the performance of sacrifice.

Conversely, sacrifice is not only a more evolved behaviour by virtue of being limited to the human world but also a superior behaviour to the extent that it organises the contingencies of the self by spiritual lines. The fury, which is redirected against a third innocent party unable to retaliate, is controlled through sacrifice, and at the same time, sacrifice becomes conditioned by the scapegoat, thus creating a relationship of mutuality and interdependency.

\section{The religious scapegoat}

The primitive societies understood that collective violence was an unlimited cycle of harm revenge, which could only end in mutual loss, death and destruction. At the same time, just as in working with children, the primitives understood that the cycle of collective violence can be disrupted and evaded through imitative magic tricks (Frazer 1996:15-45), and theatrics similar to those used in calming the children. Because of their effectiveness, such imitative magic tricks and theatrics were repeated to the point that they evolved into sacrificial rituals, whereby violence performed against an object, an animal or against another human being lacking the capacity to retaliate (Frazer 1996:693-703) was soon perceived as 'nothing more than the regular exercise of "good" violence' (Girard 1979:37).

Through meaning-making and storytelling, a theological superstructure was built around scapegoating rituals. The focus of the theological superstructure was on efficacy as the narrative had to be matched by successful empirical results. The scapegoat became the epicentre of analysis, and it was charged with dual contrasting powers. It was pure and contaminated, attractive and repudiated, beautiful and ugly and good and evil. 
Because the scapegoat was to be destroyed, the contact with such prospective victim was to be avoided. Furthermore, any violence conducted against the prospective victim outside the ritual setting implied a profound sense of contamination for the community itself. (This process is similar to the modern society's attitude towards death penalty, whereby it is the community, through its legal authority, that puts a criminal to death so that the victim's family or clan will not become contaminated by the spirit of murder and vengeance.) The scapegoat can be real, such as a prized object, an indispensable animal or a human being which the group itself refuses to accept: an outsider, or a deviant insider, or even someone regarded as cursed because of a physical defect or illness that generates fear of contamination. The scapegoat can also be metaphorical such as an invisible entity, an evil concept or thought, an insignificant object, a demon or evil itself (Girard 1986).

The apparently cognitive dissonance of shifting blame or retaliation into a weaker victim is, in fact, a phylogenetic phenomenon noted in the animal world, and it goes beyond human rationality. As Lorenz (1966) noted by studying animal behaviour, determined by specie's preservation, the 'redirection of the attack is evolution's most ingenious expedient for guiding aggression into harmless channels', and that it is in the animal's:

$[B]$ lind trial and error, or to be more exact, trial and success, that they often hit upon several possible ways of dealing with the same problem, and use them all to make its solution doubly and triply sure. (p. 54)

In light of this multiplicity of attempts to resolve a problem, religious scapegoating was practised not only overtly but also covertly through deceptive charity which involved contamination. Internally, the contamination of the scapegoat prevented the scapegoat from becoming an object desired by the internal competitors, who could continue to generate instability, and externally, it transferred evil away from the community. As a result, the contamination of the scapegoat was both symbolic (as it contained evil itself) and real (as it often contained narcotics or poison.) For instance, in ancient Middle East, during the Jewish Yom Kippur ritual of Atonement, the high priest sacrificed two goats: one as an offering to Jehovah and the second sent out in the wilderness, carrying all the sins of the tribe away from the community (Lv 16:18-22). It was therefore a symbolic as well as a real gift of deception given to whoever would benefit from it in the wilderness, whether savage beasts or rival humans. By receiving such a 'gift', the savage beasts or rival humans would be satisfied and eventually renounce their attack against the community. In the same way, in the context of the Ašhella ritual performed during war, the Hittites used an attractive woman, a ram and bread, which they sent to the enemy camp to transfer the evil away from their own community (Westbrook \& Lewis 2008:417-422). Furthermore, in time of war, the Cretans drugged a bull which they sent to the enemy camp as a deceptive gift, which once slaughtered and eaten by the enemies would intoxicate the enemies and thus the enemies could easily be overrun by the Cretans (Burkert 1979:59-60).

The deception played a double role. It deceived the giver as well as the receiver, because this prized object was not given out of generosity but as a scapegoat for social healing and spiritual purification, whereby evil was transferred unto the gift, and through the gift it was transported away from the group. For example, Douglas (1995:31-48) identified a widespread surviving medieval practice of sin-eating, whereby tasty alimentary gifts that were spiritually contaminated were given away as gifts. Insofar as a practice from my native village in the Carpathians counts as evidence, the almsgiving performed during a funeral does not necessarily carry out the functions of social charity. Rather, it serves as a vehicle for transferring the un-expiated sins of the dead back unto the living, who are now obliged to redeem such sins through various acts of penance. Once the living receives a gift from the deceased's family - particularly the coliva, a ritual meal of boiled grains symbolising the community as well as the body of the deceased - the receiver becomes contaminated with the un-expiated sins of the dead - now having to perform acts of penance for spiritual self-cleansing in order to get rid of the sins received from the dead. Obviously, all these strategies surrounding the strategic use of the scapegoat were designed to put an end to violence and banish it away from the community.

\section{The ritual of sacrifice}

With the sacrificing of the scapegoat, the violent relationship between people is increasingly controlled through the symbolic action of the seer, which leads to the recognition of the seer as a prophet. Within this new position of power, the prophet is not only 'a purely individual bearer of charisma, who by virtue of his mission proclaims a religious doctrine or divine commandment' (Weber 1977:253), but also someone who 'demands obedience as an ethical duty' (Weber 1977:263), thus setting new laws, whether as a founder or as a renewer of a religion. The prophet therefore (re)defines the interaction between the members of the group, as well as with an out-group in order to offer 'a unified view of the world derived from a consciously integrated and meaningful attitude toward life' (Weber 1977:266). This attitude towards life is based on a power structure designed to lead the group towards salvation, while 'balancing the guilt and merit of individual actions in a very precise bookkeeping and determining the religious fate of the individual person according to the outcome of this accounting' (Weber 1977:271). The sacrificial ceremony itself is a source for power accumulation because it involves a type of behaviour reserved only for special occasions, thus building a structure based on symbols and rules of the ritual, as revealed by the early developments of Brahmanism (Nayak 2000:66-70).

Nevertheless, with the development of the human society, sacrifice is gradually replaced by the juridical system, both within the process of religious institutionalisation and as a 
parallel secular endeavour. Thus, legislation eliminated the need for sacrifice because this third-party authority (which is not contaminated by the dispute) becomes the very penal system defined by universally applicable laws meant to offer a fair punishment. Various anthropologists such as Lienhardt (2003), Turner (1981), Pritchard (1956) and others have already demonstrated that ritual action is more dominant in societies deprived by a reliable judicial system, because 'ritual in general, and sacrificial rites in particular, assume essential roles in societies that lack a firm judicial system' (Girard 1979:18).

The legislative process also eliminates the need for sacrificial ritual because (Girard 1979):

$[T]$ he function of the judicial system is ... more concerned with the general security ... a decisive difference between primitive and civilized man is the former's general inability to identify the guilty party and to adhere to the principle of guilt. (p. 22)

In other words, vengeance is not self-perpetuating because the preventive role that sacrifice played is now translated into judicial retribution, and the ' $[t]$ he judicial authority is beholden to no one. It is thus at the disposal of everyone, and it is universally respected' (Girard 1979:23).

With the increase in legalisation, the interest in sacrifice decreases dramatically in the society in general. Nevertheless, law fails to replace sacrifice completely because sacrifice regains its dominance in situations where law is either ineffective or is no longer recognised as neutral third party. Furthermore, a deeper reason for the survival of the ritual even once the law made its way into social order - emerges from the ritual's complete subscription to an inherently transcendental distinctiveness - something that the law subscribes to only partially, such as in the practice of oath administration.

This transcendental quality of the ritual demonstrates that (Girard 1979):

$[M]$ en can dispose of their violence more efficiently if they regard the process not as something emanating from within themselves, but as a necessity imposed from without, a divine decree whose least infraction calls down terrible punishment. (p. 14)

Therefore, in contemporary settings of competition, ritual does not replace the law, but it complements it during special occasions, such as during political ceremonies or transitions. In conclusion, as Girard (1979:25) notes, vengeance, sacrifice and law share a fundamental identity in the sense that 'they tend to adopt the same types of violent response in times of crisis'. Even for the contemporary society, ritual performance is re-emphasised and its power is restored with each calamity faced by a group. Forgotten ritual is both a cause and a solution for the ills faced by the community, and once the ritual is performed, the calamity ceases (Burkert 1996:107-108).

\section{Meaning-making: Sacred and profane}

In the progress of religion, with each ritualised intervention in a dispute, the seer has a double scope to resolve the dispute and strengthen one's authority. In this process of meaning-making, the seer tells a deliberately ambiguous story and sets the foundation for a sacred myth. The seer tells a story that attempts to answer the fundamental questions of life as a continuum, while also setting the foundation for a theological structure. The seer does so by separating the world into two dimensions - sacred and profane - a separation that stays at the basis of territorial and temporal delimitations. With these contrasting horizons in place, the seer uses the ritual to construct the sacred space, makes the distinction between chaos and order and reorients the human towards an idea of 'centre'. Time-space demarcations offered a solid basis for the institutional design of the organised religion, as dictated by the rules of ritual, such as in the case of the primitive Vedic rituals used in taking possession of a territory (and making it legally valid) through the erection of an altar (Eliade 1987:22, 29, 30). Therefore, interpersonal violence can only be validated as therapeutic if performed under the conditions of sacred in the appropriate space and time. Any use of interpersonal violence outside the sacred is forbidden and repudiated.

\section{Ethics of guilt and punishment}

The ethics of guilt and punishment emerged from the patterns of child psychology, which were transferred into the society, and appealed to not only in the daily behaviour but also whenever the group was faced with a collective crisis. Here, the seer identified the guilt and applied appropriate punishment through a diagnosing process which involved the four stages mentioned previously, such as the occurrence of evil, the intervention of the seer as mediator, the diagnosis of the hidden cause and the application of the corresponding atonement.

As for the identification of guilt which, according to Burkert (1996:103), had triggered the fury of the uncontrollable forces - a fury which demanded the application of appropriate atonement-Burkert further clarifies that, ' $[g]$ uilt is commonly attributed to the breaking of religious taboos, neglect of sacrifices, or violation of sacred rules' (Burkert 1996:113) - all to the seer's advantage. On the long term, each new calamity provided a new opportunity for the seer to refresh and rehabilitate the authority of religion as well as his or her own authority through a pattern of symbolic behaviour meant to separate the structure and the meaning of life between matters that are numinous and foul (Simion 2017:1-2), and as such to find a cure and provide social stability.

\section{Organised religion: Symbolic violence, theological superstructure and structural ambivalence}

With the increased authority of the seer over the group, both violence and religion become incrementally institutionalised. Through repetition, the practice of scapegoat and sacrifice led to the establishment of complex religious rituals that distinguished between the benefits of controlled violence and the destructive dangers of uncontrolled violence. Guilt and punishment, which derived from child psychology, 
led to the development of sacred precepts that transitioned from taboos into intelligible laws. The separation of human activity between sacred and profane led to the development of sacred narratives that defined the meaning of life by attempting to answer the fundamental whys and hows of human existence. Furthermore, primitive religion reached its maturity and consolidated itself through the crafting of sacred narratives, through the imposition in public and private behaviour of rules that synchronised with the corresponding narratives, and through the stylised behaviour of ritual which advanced the seer's interests to stabilise the group and maximised the seer's moral authority.

It is also important to note that the transition from primitive to advanced organised religion only expanded the complexity of doctrines, ethics and rituals; it did not re-invent them. Religious narrative shifted from a primitive myth to more complex sacred texts and theological superstructures. The advanced myth only modified or replaced the primitive myth; it did not invent the myth or the idea of myth itself. In other words, if the sacred-versus-profane demarcation of the primitive religion created the narrative of meaning, in advanced religion, religious meaning was further embellished through the production of scriptures which became sources for dogmatic validations of truth.

The concepts of guilt and punishment from primitive religion evolved into the establishment of standards of collective behaviour which were more flexible, such as canons, or they emerged into very strict laws that favoured the seer or the political potentate. The phenomena of sacrifice and scapegoating had been increasingly virtualised and transferred to the symbolic space, where violence reduced significantly the physical pain. Furthermore, physical pain became a matter of personal choice and was practised more for devotional goals in the forms of severe asceticism as seen in Hinduism, Buddhism and Christianity, as self-inflicted punishment as seen in the prolonged kneeling, starvation, self-flagellation and other forms of austerities found throughout the contemporary living religions.

As far as violence is concerned, a highly significant achievement of the transition from the primitive to the advanced state of organised religion is the institutionalisation of ambivalence by the seer. Anchored into the efficacy of the sacrifice, the therapeutic power of controlled violence was to be used under circumstances determined exclusively by the seer, as much as the seer appealed to peace. In this sense, the seer could use freely the tools of peace or the tools of limited violence in resolving a conflict. When using the tools of religion, the seer selected the appropriate sacred texts in an attempt to justify either peace or limited violence, as much as the seer's choice of rituals did in enforcing a settlement via peaceful or coercive means. In the Appendix, we provide an orientation chart with the basic concepts, rituals, laws and sacred texts from five contemporary religions which demonstrate that the ambivalence towards violence is an intrinsic part of organised religion. This further demonstrates that the contemporary religions are equipped with tools such as doctrines, ethical rules, rituals and sacred texts to enforce peace or use violence when attempting to manage a conflict.

\section{Conclusion}

In concluding these correlations between interpersonal violence and the progression of organized religion, it is important to remember the following: Firstly, this article demonstrated that interpersonal violence is a dynamic that appears to have influenced the progression of organised religion far more than what we are ready to accept. Through transition rituals, the overlapping triangulating mechanism of interpersonal conflict had been transplanted from under the jurisdiction of the caretaker to that of the seer, while the mechanism of mimetic violence revealed by child psychology along with its resolve into scapegoating and guilt was relocated into the social life as a continuum. Secondly, it demonstrated that religion is not inherently violent, and that its use of limited violence is exclusively therapeutic for the group, and designed to ensure its survival. Thirdly, it demonstrated that advanced religion made significant progress in transferring the meaning of violence from real to symbolic. It did so through the virtualisation of the scapegoat and through a change in the hermeneutics of violence which abandoned physical confrontation in favour of spiritual warfare. Fourthly, it demonstrated that organised religion built tools to enforce peace directly (as pacifism) and indirectly (via limited justifications of violence) through doctrines, sacred texts, ethical principles and rituals.

\section{Acknowledgements}

The author would like to thank the editors and the anonymous reviewers for their valuable work and suggestions.

\section{Competing interests}

The author declares that he has no financial or personal relationships that may have inappropriately influenced him in writing this article.

\section{Author(s) contributions}

I declare that I am the sole author of this article.

\section{Ethical consideration}

This article followed all ethical standards for a research without direct contact with human or animal subjects.

\section{Funding information}

This research received no specific grant from any funding agency in the public, commercial, or not-for-profit sectors.

\section{Data availability statement}

Data sharing is not applicable to this article as no new data were created or analysed in this study.

\section{Disclaimer}

The views and opinions expressed in this article are those of the author and do not necessarily reflect the official policy or position of any affiliated agency of the author. 


\section{References}

Burkert, W., 1979, Structure and history in Greek mythology and ritual, University of California Press, Berkeley, LA.

Burkert, W., 1986, Homo Necans: The anthropology of ancient Greek sacrificial ritual and myth, University of California Press, Berkeley, LA.

Burkert, W., 1996, Creation of the sacred: Tracks of biology in early religions, Harvard University Press, Cambridge, MA.

Denzler, M. \& Förster, J., Liberman, N., 2009, 'How goal-fulfillment decreases aggression', Journal of Experimental Social Psychology 45(2009), 90-100. https:// doi.org/10.1016/j.jesp.2008.08.021

Dollard, J., Doob, L.W., Miller, N.E., Mowrer, O.H. \& Sears, R.R., 1939, Frustration and aggression, Yale University Press, New Haven, CT.

Douglas, T., 1995, Scapegoats: Transferring the blame, Routledge, New York.

Durkheim, E., 1969, The elementary forms of the religious life, The Free Press, New York.

Eliade, M., 1974, The myth of eternal return or, cosmos and history, Princeton University Press, Princeton, NJ.

Eliade, M., 1987, The sacred and the profane: The nature of religion, A Harvest Book Harcourt Brace \& World, Inc., New York.

Fisher, M.P., 2008, Living religions, 7th edn., Pearson Prentice Hall, Upper Saddle River, NJ.

Frazer, J., 1996, The golden bough, Penguin Books, New York.

Freud, S., 1998, Totem and taboo, Dover Publications, New York.

Girard, R., 1977, 'Violence and representation in the mythical text', Comparative Literature 92(5), 922-944. https://doi.org/10.2307/2906884

Girard, R., 1979, Violence and the sacred, The John Hopkins University Press, Baltimore, MD.

Girard, R., 1986, The scapegoat, The Johns Hopkins University Press, Baltimore, MD.

Girard, R., 1987, Things hidden since the foundation of the world, Stanford University Press, Stanford, CA.
Girard, R., 1996, The Girard reader, ed. J.G. Williams, Crossroad Press, New York. Girard, R., 2001, I see satan fall like lightening, Orbis Books, Maryknoll, NY.

Hubert, H. \& Mauss, M., 1981, Sacrifice: Its nature and functions, University of Chicago Press, Chicago, IL.

Juergensmeyer, M., Kitts, M. \& Jerryson, M., 2013, The oxford handbook of religion and violence, Oxford University Press, Oxford.

Lienhardt, G., 2003, Divinity and experience: The religion of the Dinka, Oxford University Press, New York.

Lorenz, K., 1966, On aggression, Harcourt Brace \& World, New York.

Moosajee, M., 2003, 'Violence - A noxious cocktail of genes and the environment' Journal of the Royal Society of Medicine 96(5), 211-214.

Nayak, A., 2000. Religions et violences: Sources et interactions. Symposium, Editions Universitaires, Fribourg.

Pals, D.L., 2006, Eight theories of religion, 2nd edn., Oxford University Press, New York.

Simion, M.G., 2012, Religion in political conflict: a constructivist theoretical model for public policy analysis, design, and implementation, PHD thesis, Northeastern University, Boston.

Simion, M.G., 2017, 'The ambivalence of ritual in violence: Orthodox Christian perspectives', HTS Teologiese Studies/Theological Studies 73(3), a4526. https:// doi.org/10.4102/hts.v73i3.4526

Sir Pritchard, E.E.E., 1956, Nuer religion, Oxford University Press, New York.

Sparks, J.B., 2013, Time chart of world religion: A histomap of faith through the ages, Sterling Metro Books, New York.

Turner, V.W., 1981, The drums of affliction: A study of religious process among the Ndembu of Zambia, Cornell University Press, Ithaca, NY.

Weber, M., 1977, On charisma and institution building, Chicago University Press, Chicago, IL.

Weber, M., 1991, The sociology of religion, Beacon Press, Boston, MA.

Westbrook, R. \& Lewis, T.J., 2008, 'Who led the scapegoat in Leviticus 16:21?', Journal of Biblical Literature 127(3), 417-422. https://doi.org/10.2307/25610131 


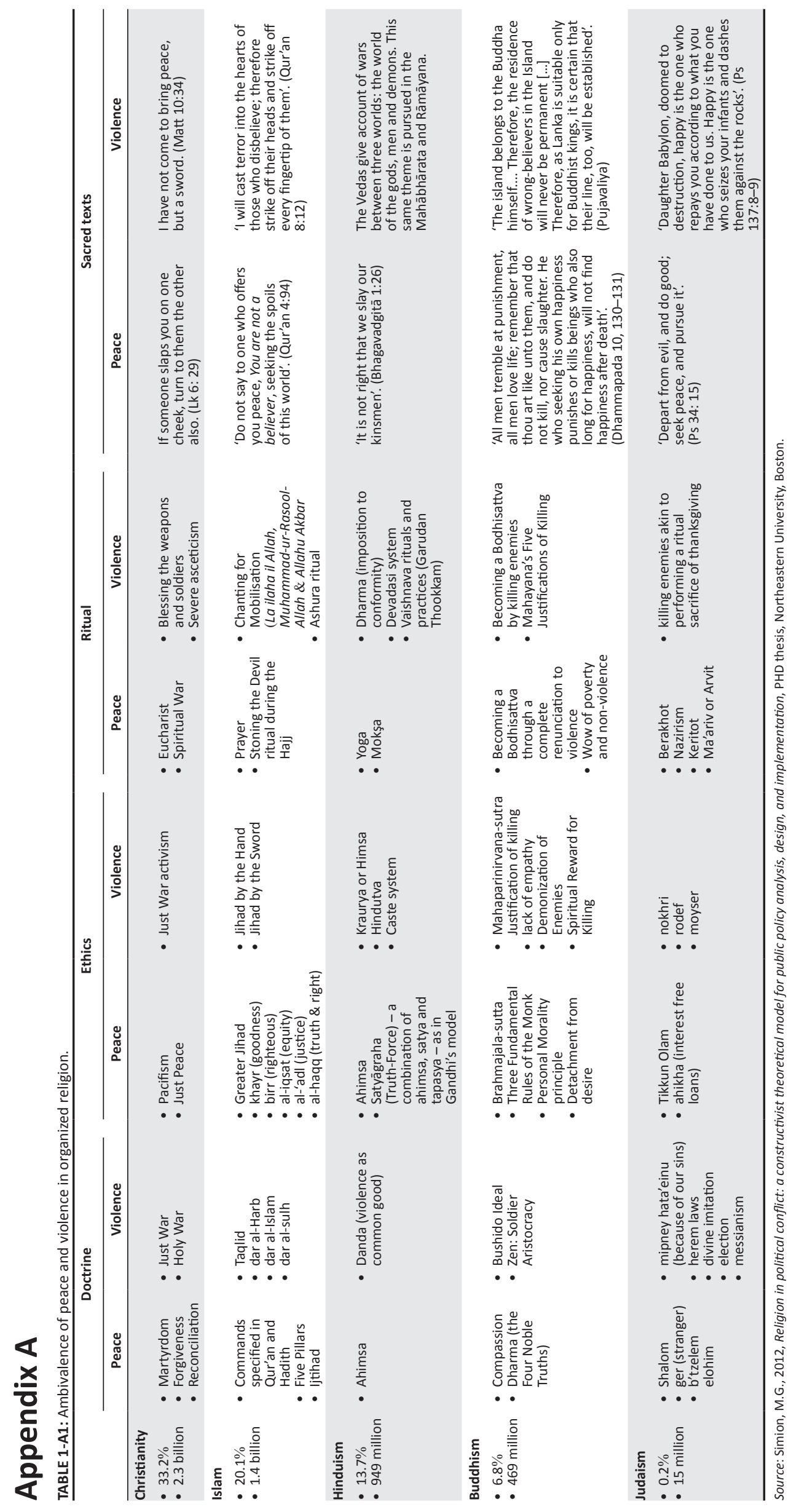

